This Michigan State Summary educates policymakers and the public

about EERE investments and their positive impacts in Michigan.
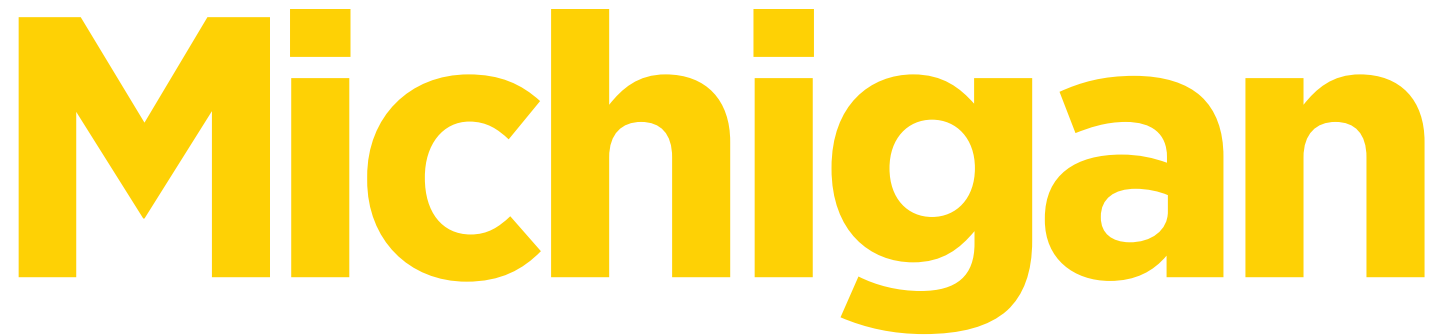

The U.S. Department of Energy (DOE) is pursuing an all-ofthe-above approach to developing every source of American energy. The Office of Energy Efficiency and Renewable Energy (EERE) leads DOE efforts to build a strong clean energy economy, a strategy that is aimed at reducing our reliance on foreign oil, saving families and businesses money, creating middle-class jobs, and reducing pollution.

This strategy will position the United States as the global leader in clean energy, increasing our nation's competitiveness. In 2012, \$268 billion was invested globally in clean energy, a $500 \%$ increase since $2004 .{ }^{8}$ Trillions of dollars will be invested in the coming decades. Clean energy represents one of the most important economic development races of the 21 st century. We face a stark choice - the clean energy technologies of tomorrow can be invented and manufactured in Michigan and the rest of the United States for domestic use and export around the world, or we can cede global leadership and import those technologies from China, India, Germany, and elsewhere.

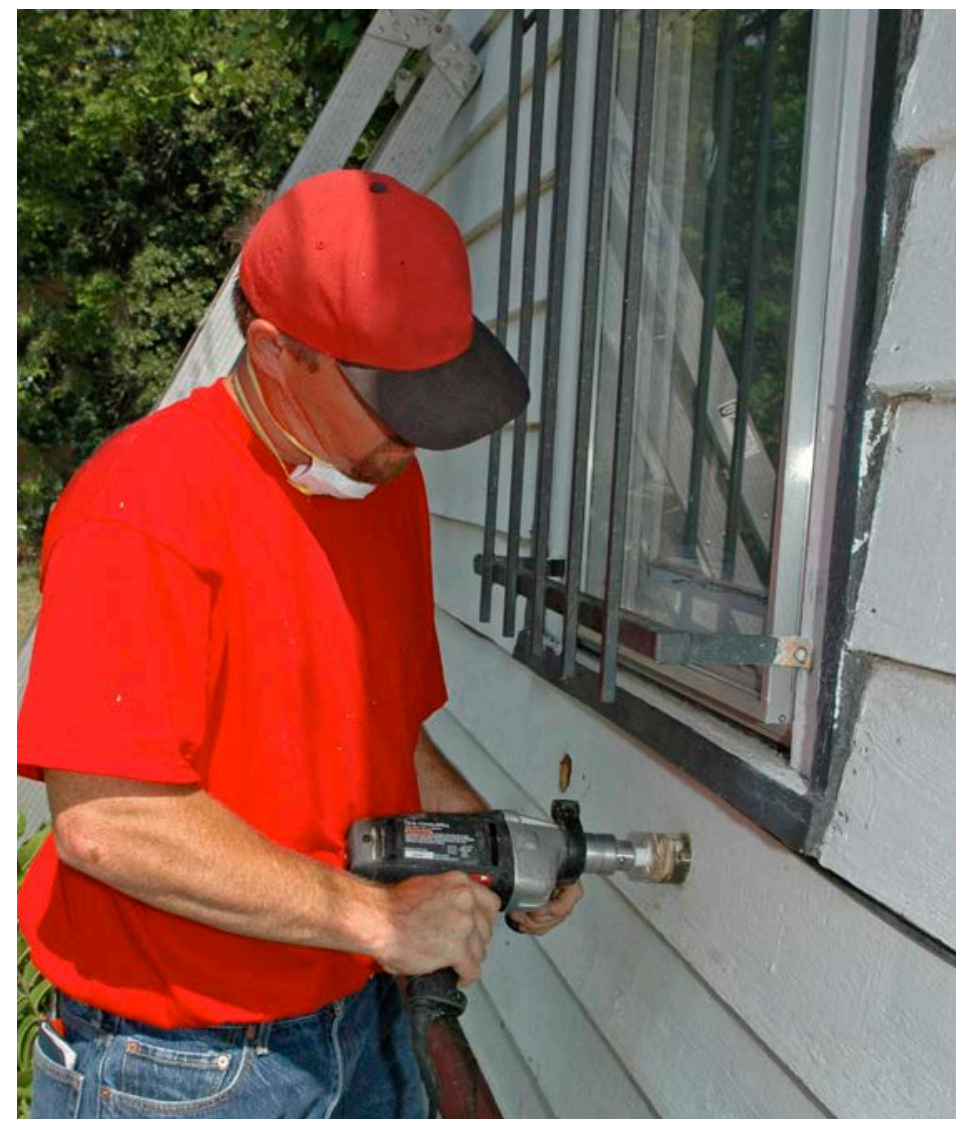

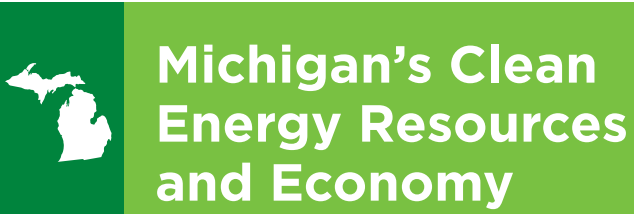

- Clean Economy Jobs (2010): 76,900+

- Average Annual Growth Rate of Clean Economy Jobs (2003-2010): $-0.3 \%$

- Average Annual Wage of Clean Economy Jobs (\$2009): $\$ 40,558^{1}$

By harnessing its abundant supply of conventional hydroelectric power, biomass, and wind, Michigan is well on its way to meeting its goal, set by the 2008 Clean Renewable and Efficient Energy Act, of generating 10\% of retail electricity from renewable sources by 2015 . Renewable biomass accounted for $39 \%$ of renewable energy credits certified in Michigan between 2009 and 2011, thanks in part to Michigan's 19 million acres of forest land. ${ }^{2}$ Small hydroelectric plants, landfill gas, and municipal solid waste are all important sources of renewable electricity in Michigan-together accounting for $34 \%$ of renewable energy credits during the same time period. ${ }^{3}$ Michigan also has significant undeveloped wind energy potential. ${ }^{4}$

Michigan also requires electric providers to develop and fund "energy optimization" programs aimed at reducing electricity consumption. Michigan is one of the few states to count efficiency as an eligible clean energy resource, awarding "energy optimization credits" for successfully reducing energy consumption. Energy optimization credits can be substituted for renewable energy credits. As of December 2009, all utility customers in Michigan are eligible to participate in at least one energyefficiency program offered through a local utility, and aggregate statewide funding for energy optimization programs has more than tripled from \$67 million in 2009 to $\$ 208$ million in $2011{ }^{6}$

Michigan is becoming a center for the domestic advanced battery industry. Companies all along the battery supply chain cluster in the state and draw from a talented pool of scientists, engineers, and other skilled workers with decades of experience in the auto industry. Michigan's geographic position makes the state an attractive site for wind industry manufacturing; 2010 counted 31 wind technology manufacturing facilities in the state. ${ }^{7}$ 


\section{EERE and Michigan}

EERE helps create Michigan's clean energy economy today, developing and delivering innovative, market-driven solutions for the following:

- Sustainable transportation - making transportation cleaner and more efficient through solutions that put electric drive vehicles on the road and replace oil with clean domestic fuels

- Renewable electricity generation - reducing the cost of renewable energy through solutions that squeeze more usable power from sustainable resources and improve the economics of manufacturing and installation

\section{- Energy-saving homes, buildings, and manufacturing -} developing cost-effective energy-saving solutions that help make our country run better through increased efficiency_-promoting better plants, manufacturing processes, and products; more efficient new homes and improved older homes; and other solutions to enhance the buildings in which we work, shop, and lead our everyday lives.

\section{EERE Investments in Michigan}

EERE invests in Michigan through a broad range of clean energy projects, from energy efficiency to vehicles, wind, biofuels, fuel cells, solar, and other technologies. Through the research, demonstration, and deployment activities we conduct with Michigan and its businesses, universities, nonprofits, and local governments, EERE supports cities, communities, and families to develop innovative, cost-effective energy solutions.

\section{Sustainable Transportation}

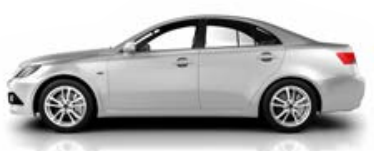

\section{EERE and the Big Three Collaborate to Advance Clean Vehicle Technologies}

EERE investment: \$173.1M (General Motors); \$91.7M (Ford); \$72.4M (Chrysler)

General Motors, Ford, and Chrysler are all partnering with DOE on a number of competitively funded projects. All three companies are participating in electric drive vehicle testing and evaluation, which will help inform the development of advanced vehicle technologies. General Motors' research and development projects include developing advanced technology powertrains, thermoelectric devices, and power inverters. Through the American Recovery and Reinvestment Act (ARRA), EERE is also supporting an effort to expand General Motors' capacity to produce lithium-ion battery packs for plug-in electric vehicles. General Motors and its partners are contributing $\$ 253$ million to these projects. With EERE's support, Ford is working to develop advanced fuels and lubricants, thermoelectric devices and advanced powertrains. Ford and its partners are contributing $\$ 90 \mathrm{M}$ to these projects. EERE is also supporting an ARRA project to expand an existing Ford facility to build electric drive transaxles with integrated power electronics for hybrid electric and plug-in vehicles. Chrysler is partnering with EERE through ARRA to develop advanced technology powertrains. Chrysler and its partners are contributing $\$ 80 \mathrm{M}$ to these projects.

\section{Biorefinery Produces Fuel from Wood Waste}

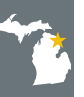

Alpena, Michigan

EERE investment: \$17.9M

American Process Inc. is completing its Alpena Prototype Biorefinery (APB) at the existing Decorative Panels International (DPI) hardboard manufacturing facility in Alpena, Michigan, with the support of an EERE investment. The goal of the APB is to demonstrate a financially viable process of making cellulosic ethanol from woody biomass extract, a byproduct of wood processing. The APB pilot is expected to be fully operational in early 2013 . The project will create 19 new jobs and will help retain 200 jobs associated with the existing DPI facility. The APB pilot biorefinery will produce 894,200 U.S. gallons per year of cellulosic ethanol and 696,000 gallons per year of aqueous potassium acetate, which is used as a de-icer for airplanes. ${ }^{9}$

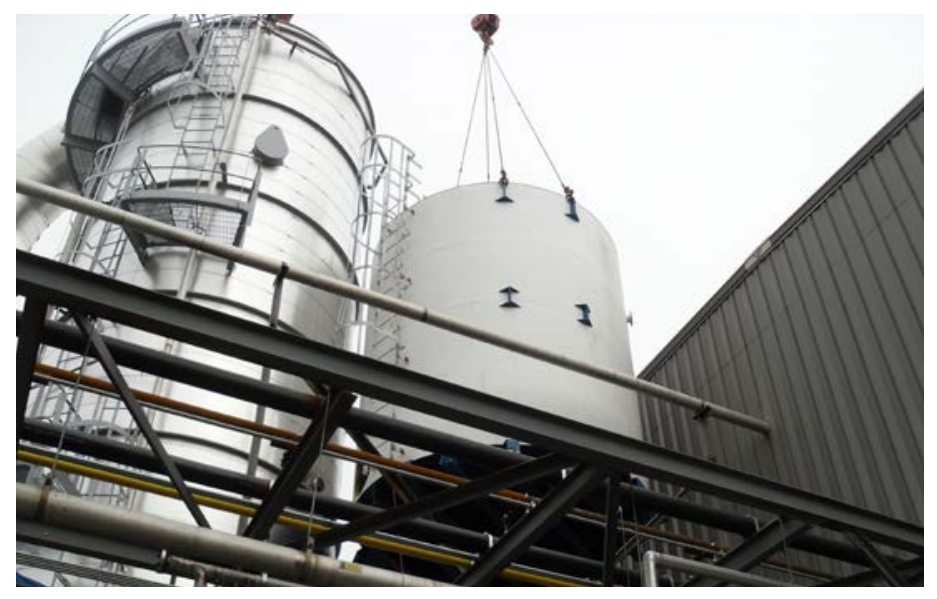

Alpena Biorefinery Construction. Photo from American Process, Inc.

\section{Commercial Scale Biorefinery to Produce Ethanol through Advanced Consolidated Bioprocessing}

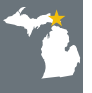

Kinross Charter Township, Michigan

EERE investment: \$100M

The Mascoma Corporation's Frontier Bioenergy Project, supported by an investment from EERE funds, will produce 20 million gallons of ethanol per year from a daily supply 
of approximately 700 dry metric tons of renewable woody biomass feedstock. The biorefinery will use Mascoma's proprietary Consolidated Bioprocessing platform, which avoids some complex processing steps, providing a "one-step" route to producing cellulosic biofuels. This innovative bioenergy technology results in a $60 \%$ reduction in greenhouse gas emissions when compared to conventional fossil fuels. The project is expected to create between 40 and 60 permanent jobs and between up to 150 temporary jobs during construction.

\section{EERE and Auto Manufacturers Demonstrate and Evaluate Fuel Cell Vehicles}

Detroit, Michigan

EERE investment: $\$ 140 \mathrm{M}$

Over the last 6 years, the National Fuel Cell Electric

Vehicle Learning Demonstration - funded and managed by EERE - has tested, demonstrated, and validated fuel cell electric vehicles and hydrogen infrastructure. The project found that these vehicles achieved more than twice the efficiency of today's gasoline vehicles, with refueling times of about five minutes. Four teams took part in the Learning Demonstration, in which auto manufacturers Ford Motor Company, Hyundai, Kia, Daimler/Chrysler/Mercedes-Benz R\&D North America, and General Motors participated. The teams collected data from 183 fuel cell electric vehicles taking more than 500,000 trips totaling 154,000 hours of operation with more than 3.6 million miles traveled. They also collected data from 25 fueling stations, which refilled the vehicles approximately 33,000 times while dispensing 152,000 kilograms of hydrogen. Project partners contributed $\$ 164$ million to this effort. In general, switching from a gasoline engine to a hydrogen fuel cell could reduce emissions by more than $90 \%$.

\section{Developing Advanced Batteries for Electric Drive Vehicles}

Transitioning America's vehicle fleet to electric-drive vehicles could reduce U.S. foreign oil dependence by more than $60 \%$ and greenhouse gas emissions by $40 \%$, while increasing the nation's energy security. Developing electric drive trains and low-cost batteries is essential to reducing the cost of electric drive vehicles, including hybrid, plug-in hybrid, and all-electric vehicles. EERE has supported efforts by several Michigan firms to develop improved batteries and drive trains, reduce costs, and scale up production of electric vehicle technology.

\section{- US ABC Collaborates to Lower Cost of Electric Drive Batteries}

Various locations throughout Michigan EERE investment: $\$ 7.5 \mathrm{M}$

The U.S. Advanced Battery Consortium (US ABC) is a group that funds electrochemical storage research and development. The group consists of Chrysler, Ford, and General Motors and partners with EERE to support these projects with both funding and non-financial resourcessuch as testing facilities. The partnership has supported a number of up-and-coming battery companies. This collaboration has allowed all of the partners to benefit from the research. EERE-supported US ABC research has helped reduce production costs of automotive lithium-ion batteries by $50 \%$ since 2008 . The participating companies dedicated \$7.5 million toward US ABC in 2011.

\section{- Universities Train Next Generation of Automotive Engineers}

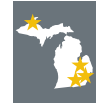

Detroit, Michigan (Wayne State and University of Michigan); Warren, Michigan (Wayne State); Houghton, Michigan (Michigan Technological University); Ann Arbor, Dearborn, and Flint, Michigan (University of Michigan)

EERE investment: \$5M to Wayne State; $\$ 2.5 \mathrm{M}$ to University of Michigan; $\$ 1.25 \mathrm{M}$ to University of Michigan-Dearborn; $\$ 2.98 \mathrm{M}$ to Michigan Technological University (Michigan Tech also has a separate $\$ 1.8 \mathrm{M}$ research project)

Wayne State University, Michigan Technological University and the University of Michigan are all carrying out Advanced Electric Drive Vehicle Education programs to educate future engineers about electric drive vehicles. All three universities are developing courses and concentrations for undergraduate and graduate students in electric drive technology. Michigan Tech, with partners at Kettering University and Pennsylvania State University, is offering short courses for engineers and operates a mobile vehicle laboratory that provides hands-on experience to audiences ranging from elementary school to graduate researchers. Wayne State also has a robust public outreach program. University of Michigan-Dearborn is developing new graduate programs and courses in electric drive transportation that combine fundamental, interdisciplinary, and applied research. Wayne State contributed $\$ 1.25$ million to its project; University of Michigan contributed $\$ 985,000$ to its projects; and Michigan Tech and its partners contributed $\$ 1.07$ million to its projects. 


\section{- Alternative Fuel Vehicle and Infrastructure Expansion Improves Energy Security}

Statewide, headquartered in Ypsilanti

EERE investment: $\$ 14.9 \mathrm{M}$

EERE, through an ARRA investment, has supported the Michigan Green Fleets Initiative, headed by the Clean Energy Coalition, which is deploying 55 alternative fueling and charging stations. It has also put more than 460 alternative fuel vehicles on the road, including heavy and light-duty electric drive, propane, and natural gas vehicles. Participating fleets vary in size and have numerous applications, including school transportation, refuse, and package delivery. The Michigan Green Fleets Initiative is estimated to displace the equivalent of more than 1.32 million U.S. gallons of gasoline per year.

\section{- Clean Cities Coalitions Help Stakeholders Choose Smart Transportation Solutions}

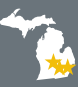

Detroit, Ann Arbor, and Lansing

EERE investment: $\$ 30 \mathrm{~K}$ annually to each coalition

EERE coordinates a network of nearly 100 Clean Cities coalitions - self-organized groups of local community, government, and business stakeholders whose efforts to adopt smart transportation solutions have displaced more than 4.5 billion gallons of gasoline and diesel since 1993.

Michigan is home to three Clean Cities coalitions: Detroit Area Clean Cities, Ann Arbor Clean Cities and Greater Lansing Area Clean Cities. In 2011, these three coalitions reduced fuel consumption by the equivalent of more than 5.5 million U.S. gallons of gasoline and prevented nearly 35,000 tons of greenhouse gas emissions. Together, the coalitions include more than 900 businesses, local governments, and other organizations, and work to promote the use of the more than 900 alternative fuel and charging stations in Michigan. In 2011, the three coalitions leveraged DOE's support to raise more than $\$ 800,000$ from businesses, local governments, other organizations, and non-DOE grants.

\section{Renewable Electricity Generation}

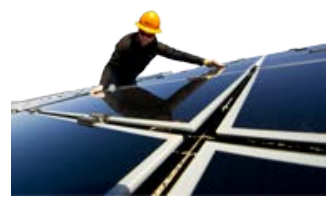

\section{Grand Valley State University: Measuring Lake Michigan's} Offshore Wind Potential

Allendale Charter Township, Michigan

EERE investment: $\$ 1.4 \mathrm{M}$

EERE partnered with Michigan's Grand Valley State

University to conduct a wind assessment study of Lake
Michigan - collecting data necessary for successful offshore commercial wind energy development in the Great Lakes. The university deployed a Wind Sentinel buoy, which has a light detection and ranging (LIDAR) wind resource measurement system on board, to make wind resource measurements at wind turbine hub heights on Lake Michigan. EERE's investment has leveraged nearly $\$ 1.9$ million in matching funds from state and local sources. Resource assessments like GVSU's provide crucial data needed by commercial offshore wind developers to properly site their projects. Commercial offshore wind development in the Great Lakes region would spur the growth of local businesses related to the wind sector, attract outside investment, expand employment opportunities and expand the wind energy research and development base within the Great Lakes Region.

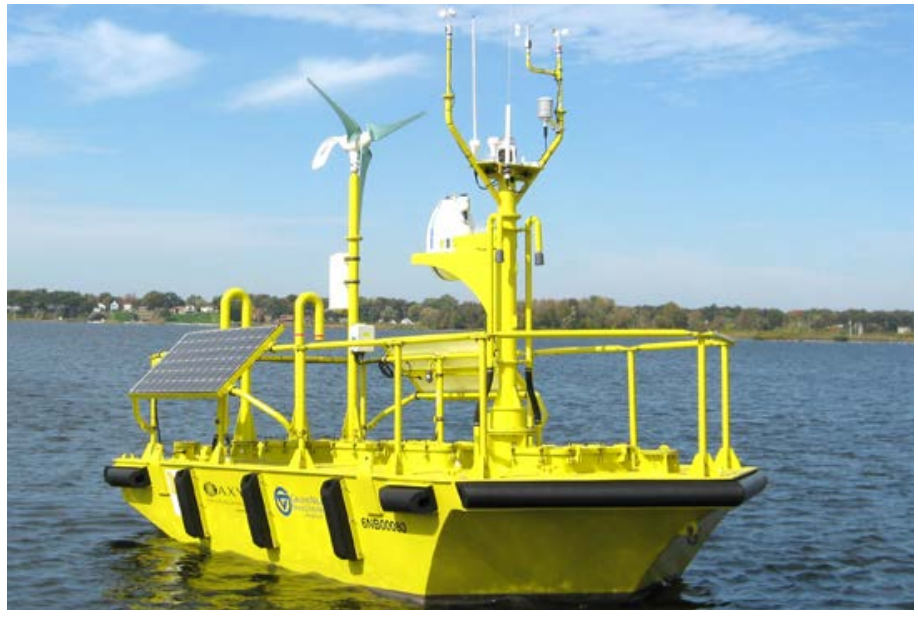

The Grand Valley State University/MAREC WindSentinel on Muskegon Lake. Photo from Arn Boezaart, GVSU.

National Center for Manufacturing Sciences: A Partnership for Faster Wind Energy System Manufacturing

Ann Arbor, Michigan

EERE investment: $\$ 761 \mathrm{~K}$

EERE provided funding to the National Center for Manufacturing Sciences (NCMS) - a not-for-profit collaborative manufacturing research consortium of 175 North American corporations based in Ann Arbor-to develop critical manufacturing technology assessments vital to bringing down the costs of producing clean energy systems. The project focused on broad, cross-cutting technologies that enable faster implementation of wind energy systems, including innovative welding techniques for manufacturing wind towers and advanced manufacturing for wind energy conversion technology. Leveraging its members' resources, NCMS' project utilized technologies from other industrial sectors and enlisted its industrial members to assess the feasibility of key manufacturing technologies. 


\section{Energy-Saving Homes, Buildings, and Manufacturing}

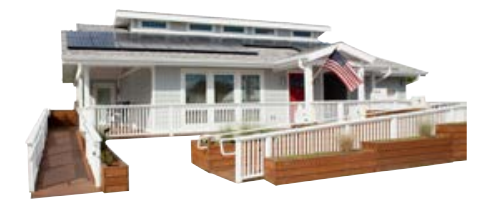

\section{HotEye $^{\circledR}$ Steel Surface Inspection System Improves Quality and Safety While Reducing Costs}

Ann Arbor, Michigan

EERE investment: \$2.4M

OG Technologies, Inc. of Ann Arbor, supported by an investment from EERE, has developed the HotEye ${ }^{\circledR}$ Rolled Steel Bar (RSB) System. The HotEye system accurately and reliably measures a steel part's dimensions during the rolling process, and detects its surface features, including defects, while it is still red hot (i.e., at temperatures of up to $1,550^{\circ} \mathrm{C}$ ). This technology is far superior to current measurement systems, which cannot be used until the parts cool down. The new system allows for lower scrap rates, reduced costs, increased productivity, and reduced energy use. By allowing remote inspection of steel parts at high temperatures, the system avoids the need for workers to be in close proximity to the hot steel, improving employee safety and reducing the risk of burns. By detecting and identifying production flaws quickly, the HotEye system reduces the scrap rate from the process by $50 \%$ - significantly boosting profitability and productivity, as well as allowing for a quick return on investment. By improving the quality of steel, the HotEye system will also improve the quality and safety of critical products, including as automobile axles and airplane fasteners. The HotEye RSB System was installed in five U.S. steel mills and multiple international mills in 2011. ${ }^{10}$

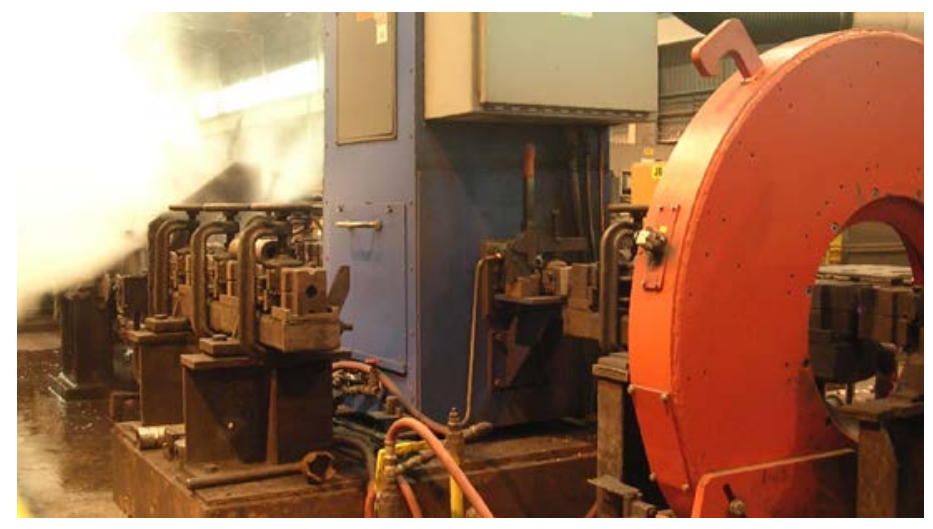

The OG Technologies HotEye ${ }^{\circledR}$ system will improve steel quality by measuring the dimensions of steel parts at temperatures up to $1,550^{\circ} \mathrm{C}$. Photo from OG Technologies, Inc.

\section{Improvement of Lost Foam Casting Process}

EERE investment: \$7.2M toward the overall effort from 1989 to today.

Cast metal products are found in virtually every sector of the economy; almost $90 \%$ of all manufactured products contain one or more metal castings. Metal casting is also an energy-intensive manufacturing process. A process called Lost Foam Casting, which has been around since 1958, offers significant cost and environmental advantages - with project energy savings of $25 \%$ to $30 \%$ compared to traditional sand casting. However, complexities and variables with the lost foam process prevented many manufacturers from using it. There was virtually no growth in the use of the process until after 1989, when DOE helped form and co-sponsor an industry group called the Lost Foam Casting Consortium dedicated to improving the state-of-the-art in this core technology. In just six years, cost-effective research partnerships co-funded by DOE and the Consortium - including GM and the American Foundry Society - increased the level of understanding and control over the lost foam casting process so dramatically that it helped boost the number of lost foam casting operations by more than $100 \%$ for aluminum castings and $300 \%$ for iron castings.

GM was just one of many companies from diverse sectors that considered the newly improved lost foam process as a means to revolutionize the way it manufactures its aluminum engine blocks and heads.. The lost foam process-control improvements have represented such a sea change in the technology that they dramatically increased the marketability and application of the underlying lost foam casting technology - paving the way for increases in the quality of parts, improvements in production efficiency, lower costs, and major reductions in both energy consumption and scrap. ${ }^{11}$

\section{EERE-Supported Appliance Rebate Program in Michigan}

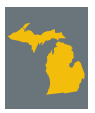

Statewide

EERE investment: $\$ 9.5 \mathrm{M}$

In 2010, Michigan implemented a residential appliance rebate program with ARRA funding from EERE. Michigan offered rebates ranging from $\$ 25$ to $\$ 2,500$ for the replacement of existing appliances with new, ENERGY STAR ${ }^{\circledR}$ qualified products, including clothes washers, dishwashers, furnaces, refrigerators, and water heaters. The Michigan Energy Office engaged in promotion campaigns with the local media outlets, including radio and TV ads, to promote the program and highlight the benefits of energy efficiency. In total, the Michigan State Energy Efficiency Appliance Rebate Program provided more than 54,000 rebates totaling $\$ 3.8$ million. The annual energy savings are estimated at 37 billion British thermal units, representing $\$ 1.6$ million in consumer cost savings. ${ }^{12}$

\section{Human Health Science Building Geothermal Heat Pump Systems}

Rochester, Michigan

EERE investment: \$2.7M

Oakland University in Rochester, with ARRA funding from EERE, built a ground-source heat pump system (256 geothermal wells) and a roof-mounted solar thermal hot 
water array (covering 6,060 square feet) to provide summer dehumidification and cooling, as well as winter space heating. These systems helped the Human Health Science Building become the first higher education academic building in the State of Michigan to achieve Leadership in Energy and Environmental Design Platinum certification, the highest such rating available. Due to these and other energy innovations, this building uses an estimated $45 \%-55 \%$ less energy than a standard building of comparable size and utilization. The recipient contributed $\$ 7$ million to this project. ${ }^{13}$

\section{Better Buildings Program "Sweeps" Michigan Neighborhoods}

Statewide

EERE investment: \$5M

Better Buildings for Michigan is a statewide program that receives support from EERE, and uses innovative neighborhood "sweeps" to reach its residential target audience. The neighborhood sweeps approach is an intensive, house-by-house campaign designed to convince homeowners in a specific neighborhood to complete a home energy upgrade. The sweeps include knocking on doors, distributing mailers, organizing community group meetings, hosting in-home informational meetings for neighbors, and sponsoring a program-wide press event with Michigan's governor. The first neighborhood sweep kicked off in Ferndale, Michigan, in November 2010, and concluded in January 2011. Sweeps have also been conducted in the communities of Grand Rapids, Dewitt, Bath, Marquette, Travese City, St. Joseph County, Wyandotte, Detroit, and Southeast Michigan. Through September 2012, Better Buildings for Michigan has completed 3,377 home energy assessments and 3,250 home energy upgrades in Michigan - a $96 \%$ conversion rate. Better Buildings has also provided training to staff representing more than 30 building contractors. ${ }^{14}$

\section{Projects to Watch}

EERE has recently provided funds for these projects as it continually invests in new, promising energy efficiency and renewable energy technologies.

\section{University of Michigan: Getting Offshore Wind Ready for Winter on Lake Michigan}

Ann Arbor, Michigan

EERE investment: $\$ 400 \mathrm{~K}$

The University of Michigan received funding from EERE to develop a modeling tool to simulate surface water ice impact on offshore wind turbine designs, especially designs involving innovative substructures. The funding will be used to augment existing computer-aided engineering tools, used for offshore wind turbine analysis, with a new module that can address the impact of ice buildup on turbine blades - a major challenge to deploying offshore wind in the Great Lakes.

\section{Vortex Hydro Energy: Transformational Technology to Harness Energy from Water Currents}

\section{Ann Arbor, Michigan}

EERE investment: \$1M

EERE is funding Vortex Hydro Energy to commercialize the Vortex Induced Vibration Aquatic Clean Energy (VIVACE) converter, which is a University of Michigan-patented marine and hydrokinetic energy device designed to harness the energy in slow-moving water currents. Conventional turbine technology targets rivers with water currents greater than 4 knots. The majority of river and ocean currents in the United States are slower than 3 knots. The VIVACE converter is designed for currents as slow as 2 knots. It is also simpler in design and more cost effective than a conventional water turbine. The VIVACE converter thus taps into a new source of clean and renewable energy. This project is focused on improving the energy conversion efficiency of the VIVACE converter in a laboratory setting, to be followed by an open water test of the improved system in the Saint Clair River at Port Huron, Michigan.

\section{Deploying Clean Energy Solutions in Michigan Communities}

EERE invests in the deployment of energy efficiency and renewable energy projects in communities across Michigan. These investments catalyze economic development, create jobs, generate clean energy, and reduce utility bills. Many of these investments are a result of the American Recovery and Reinvestment Act (ARRA). Of the more than $\$ 414$ million in ARRA funds allotted to the state of Michigan from EERE specifically for deployment projects, almost $96 \%$ has been spent as of January, 2013 through the Energy Efficiency and Conservation Block Grant Program, State Energy Program, and Weatherization Assistance Program.

\section{Building Clean Energy Infrastructure}

With financial and technical support from EERE, energy officials at the state level and in 69 communities have selected and overseen the completion of hundreds of projects that are delivering the benefits of clean energy to citizens throughout Michigan. EERE allocated more than $\$ 163$ million in ARRA funds to support activities that:

- Contributed to the increased energy efficiency of more than 1,700 buildings (more than 28 million square feet) through retrofits

- Installed more than 11,000 kilowatts in renewable energy capacity from wind, solar energy, solar thermal energy and geothermal energy systems 
- Funded nearly 300 workshops to educate more than 14,100 people in how to perform energy audits and upgrades and contribute to the installation of renewable energy systems

- Installed more than 7,700 energy-efficient streetlights.

\section{Weatherizing Homes for Lower Income Families}

Michigan has spent more than $95 \%$ of the more than $\$ 250$ million in ARRA funds it received to weatherize approximately 45,000 homes - surpassing the state's initial goal by $36 \%$. This resulted in annual energy savings of more than 1.3 million British thermal units and 119,000 metric tons of carbon pollution averted to date, which is the equivalent of taking more than 23,000 passenger vehicles off the road for a year. The projects have enabled income-eligible families to save hundreds of dollars per year on heating and cooling bills by improving their homes' energy efficiency, as well as the health and safety of home environments. ${ }^{15}$

\section{Deployment Project Examples}

\section{Reducing Energy Consumption}

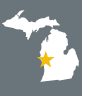

\section{Muskegon and Oceana Counties, Michigan EERE investment: $\$ 3.2 \mathrm{M}$}

The Muskegon/Oceana Community Action Partnership and Oakland Livingston Human Services Agency installed solar systems on moderate-to-low-income residential buildings and single family homes of income-qualified residents.. Completed installations include 17 solar photovoltaic arrays, 23 solar hot air systems, 12 solar hot water heating systems, and 45 hybrid water heaters.

\section{Integrated Renewable Energy Strategy}

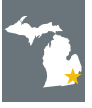

Wyandotte, Michigan

EERE investment: $\$ 3.8 \mathrm{M}$

Wyandotte Municipal Utility Services implemented the Wyandotte Integrated Renewable Energy Strategy. As of December 2012, the program performed more than 1,700 building energy audits - totaling more than 2.3 million square feet - and funded nearly 90 loans to commercial and residential customers. Additionally, several renewable energy systems have been installed in public buildings, including two solar photovoltaic systems with a combined capacity of 217 kilowatts and 17 geothermal heat pumps with the potential to produce approximately 760,000 British thermal units per year. At the end of 2012, grant funds supported a total of 89 loans, including $\$ 54,274$ of grant funds that went to buy down the interest rate of $\$ 481,976$ worth of loans for energy efficiency work in commercial buildings, as well as $\$ 98,155$ of grant funds that went to buy down the interest rate of $\$ 394,775$ worth of loans for energy efficiency work in homes.

\section{WIP Contributes to Energy Cost Reduction for City-Owned Facilities}

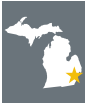

$$
\begin{aligned}
& \text { Detroit, Michigan } \\
& \text { EERE investment: nearly } \$ 1 \mathrm{M}
\end{aligned}
$$

The City of Detroit's Russell/Ferry Service Yard installed energy-efficiency upgrades, including lighting and boiler retrofits. This investment will save nearly $\$ 180,000$ in annual energy costs. The Russell/Ferry Service Yard is a 103,000-square-foot facility that is one of three maintenance centers servicing fleet vehicles. The center also houses several administrative offices and city service dispatch.

\section{References}

"Sizing the Clean Economy: A National and Regional Green Jobs Assessment." The Brookings Institution and Battelle, July 2011. http://www.brookings.edu/research/reports/2011/07/13-clean-economy; http://www.brookings.edu/ /media/Series/Clean\%20Economy/26.PDF.

2"Report on the Implementation of the P.A. 295 Renewable Energy Standard and the Cost-Effectiveness of the Energy Standards." Michigan Public Service Commission, 2012. http://www.michigan.gov/documents/ mpsc/implementation_PA295_renewable_energy2-15-2012_376924_7.pdf. 3 "Report on the Implementation of the P. 295 Renewable Energy Standard and the Cost-Effectiveness of the Energy Standards." Michigan Public Service Commission, 2012. http://www.michigan.gov/documents/ mpsc/implementation_PA295_renewable_energy2-15-2012_376924_7.pdf. 4"Report on the Implementation of the P.A. 295 Renewable Energy Standard and the Cost-Effectiveness of the Energy Standards." Michigan Public Service Commission, 2012. http://www.michigan.gov/documents/ mpsc/implementation_PA295_renewable_energy2-15-2012_376924_7.pdf s"RPS Compliance." Michigan Public Service Commission, 2012. http://www.michigan.gov/mpsc/0,1607,7-159-16393_53570---,00.html; "Enrolled Senate Bill No. 213." State of Michigan, 2012.

http://www.michigan.gov/documents/mpsc/2007-SNB-0213_254495_7.pdf.

"Report on the Implementation of P.A. 295 Utility Energy Optimization Programs." Michigan Public Service Commission, 2011. http://www. michigan.gov/documents/mpsc/eo_legislature_report2011_369985_7.pdf. U.S. Wind Industry Annual Market Report 2010, American Wind Energy Association (AWEA), 2011. http://www.awea.org/_cs_upload/ events/7302_1.pdf.

"New Investment in Clean Energy Fell 11\% in 2012." Bloomberg New Energy Finance, 2013. http://about.bnef.com/2013/01/14/ new-investment-in-clean-energy-fell-11-in-2012-2/.

"“Alpena Biorefinery." EERE, 2013. http://www1.eere.energy.gov/biomass/ pdfs/ibr_arra_api.pdf.

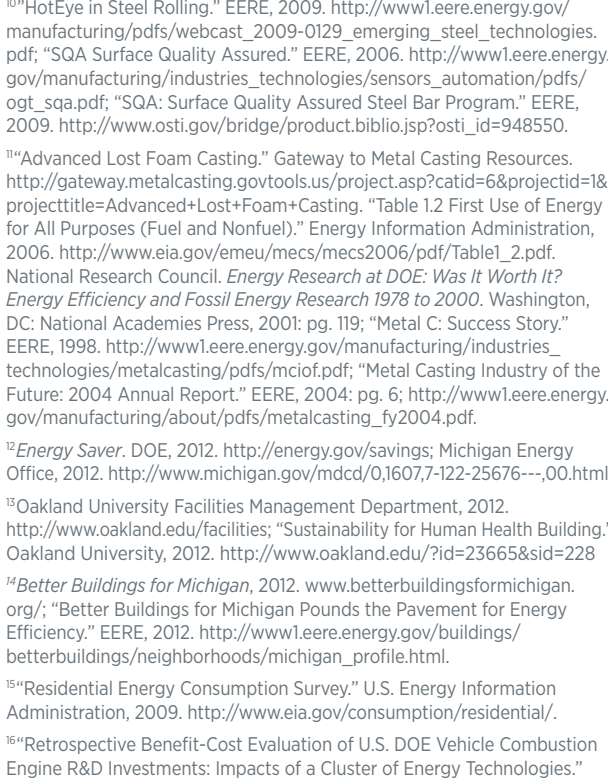

"HotEye in Steel Rolling." EERE, 2009. http://wwwl.eere.energy.gov/ manufacturing/pdfs/webcast_2009-0129_emerging_steel_technologies. pdf; "SQA Surface Quality Assured." EERE, 2006. http://www1.eere.energy. gov/manufacturing/industries technologies/sensors_automation/pdfs/ ogt sqa df. "SQA: Surface Quality Assured Steel Bar Program." EERE, 2009. http://www.osti.gov/bridge/product.biblio.jsp?osti_id=948550. 2009. http://WwW.osti.gov/bridge/product.biblio.jsp? osti_id=948550. http://gateway.metalcasting.govtools.us/project.asp?catid=6\&projectid=18 projecttitle=Advanced+Lost+Foam+Casting. "Table 1.2 First Use of Energy or All Purposes (Fuel and Nonfuel)." Energy Information Administration 2006. http://www.eia.gov/emeu/mecs/mecs2006/pdf/Table1 2 pdf. Nationat Research Council. Energy Research at DOE:Was It Worth It? Energy Efficiency and Fossil Energ Research 1978 to 2000 . Washington, Energy Efficiency and Fossil Energy Research 1978 to 2000. Washington, DC. National Academies Press, 2001. pg. 19, "Metal C. Success Story." EERE, 198. http.//Www.eere.energy.gov/manufacturing/industries_ technologies/metalcasting/pdfs/mciof.pdf; "Metal Casting Industry of the Future: 2004 Annual Report." EERE, 2004: pg. 6; http://www1.eere.energy. gov/manufacturing/about/pdfs/metalcasting_fy2004.pdf.

Energy Saver. DOE, 2012. http://energy.gov/savings; Michigan Energy Office, 2012. http://www.michigan.gov/mdcd/0,1607,7-122-25676---,00.htm

${ }^{3}$ Oakland University Facilities Management Department, 2012. http://www.oakland.edu/facilities; "Sustainability for Human Health Building." Oakland University, 2012. http://www.oakland.edu/?id=23665\&sid=228 ${ }^{4}$ Better Buildings for Michigan, 2012. www.betterbuildingsformichigan. org/; "Better Buildings for Michigan Pounds the Pavement for Energy Efficiency." EERE, 2012. http://www1.eere.energy.gov/buildings/ betterbuildings/neighborhoods/michigan_profile.html.

"Residential Energy Consumption Survey." U.S. Energy Information Administration, 2009. http://www.eia.gov/consumption/residential/

16 "Retrospective Benefit-Cost Evaluation of U.S. DOE Vehicle Combustion Engine R\&D Investments.' Impacts of a Cluster of Energy Technologies."

DOE, May 2010. http://wwwl.eere.energy.gov/analysis/pdfs/advanced

17"Retrospective Benefit-Cost Evaluation of DOE Investment in Photovoltaic Energy Systems." DOE, August 2010. http://wwwl.eere.energy.gov/ analysis/pdfs/solar_pv.pdf.

I8"Retrospective Benefit-Cost Evaluation of U.S. DOE Wind Energy R\&D Program," DOE, June 2010. http://www1 eere energy.gov/analysis/pdfs/ wind bc report10-14-10.pdf.

${ }^{19}$ National Research Council. Energy Research at DOE: Was It Worth It? Energy Efficiency and Fossil Energy Research 1978 to 2000. Washington, DC: National Academies Press, 2001.

20"DOE Hydrogen and Fuel Cells Program Record \#12020," DOE, September 27, 2012. http://hydrogen.energy.gov/pdfs/12020_fuel_cell_system cost_2012.pdf. Based on projections to high-volume manufacturing.

21" Retrospective Benefit -Cost Evaluation of DOE Investment in Photovoltaic Energy Systems." DOE, August 2010. http://www1.eere.energy.gov/ analysis/pdfs/solar pv.pdf.

22“Retrospective Benefit-Cost Evaluation of U.S. DOE Wind Energy R\&D Program," DOE, June 2010. http://www1.eere.energy.gov/analysis/pdfs/ wind_bc_report10-14-10.pdf.

23"Weatherization Assistance Program." EERE, May 2009 http://www1.eere.energy.gov/wip/pdfs/wap_factsheet.pdf. 24"Building Technologies Program: History and Impacts." EERE, 2013. http://www1.eere.energy.gov/buildings/appliance_standards/ history and impact.html.

25“Energy Technology Solutions: Public-Private Partnerships Transforming Industry." EERE, December 2010. http://www1.eere.energy.gov/ manufacturing/pdfs/itp_successes.pdf.

"Facilitating Cost-Effective Federal Energy Management" EERE, December 2012. http://www1.eere.energy.gov/femp/pdfs/femp_fs.pdf. 


\section{A Proven Track Record}

\section{Snapshot of National Outcomes from EERE Investments}

EERE's Return on Investment for Clean Energy Technologies

- EERE's $\$ 931$ million investment in vehicles combustion engine R\&D from 1986 to 2007 achieved a net benefit of \$69 billion (2008 dollars) in fuel savings for users of heavy-duty diesel trucks. ${ }^{16}$

- EERE's \$3.7 billion investment in solar photovoltaic R\&D from 1975 to 2008 resulted in a net economic benefit of \$15 billion (2008 dollars) due to module efficiency and reliability improvements. ${ }^{17}$

- EERE's $\$ 1.7$ billion investment in wind energy R\&D from 1976 to 2008 resulted in a net economic benefit of \$8.7 billion (2008 dollars) due to wind turbine efficiency, energy capture, and reliability improvements. ${ }^{18}$

- A 2001 National Academy of Sciences analysis found that investments of \$1.6 billion in energy efficiency R\&D in the first two decades of DOE's existence from 1978 to 2000 realized a net economic benefit of approximately $\$ 30$ billion (1999 dollars). ${ }^{19}$

\section{Sustainable Transportation}

- EERE research has helped reduce production costs of automotive lithium-ion batteries by more than $50 \%$ since 2008 and is on track to reach its goal of enabling cost-competitive market entry of plug-in hybrid electric vehicles within the next 10 years.

- EERE's activities to achieve cost-competitiveness for biofuels have resulted in the recent achievement of reaching a modeled cellulosic ethanol production cost of $\$ 2.15$ per gallon of ethanol (or $\$ 3.27$ per gallon of gasoline equivalent).

- EERE's efforts have reduced the projected costs of automotive fuel cells (assuming high-volume manufacturing) by more than $35 \%$ since 2008 and $80 \%$ since 2002-doubling the durability of fuel cells from 950 hours of demonstrated operation in 2006 to more than 2,500 hours of operation on the road. ${ }^{20}$

\section{Renewable Electricity Generation}

- Without EERE involvement, the average solar photovoltaic (PV) module production cost per watt would have been $\$ 5.27$ in 2008, rather than \$1.92. EERE has accelerated solar industry progress by an estimated 12 years. ${ }^{21}$

- Without EERE involvement, cumulative wind power deployment through 2008 would have been less than a third of actual 2008 levels. EERE has accelerated the overall progress of the wind industry by an estimated 6 years. ${ }^{22}$

\section{Energy-Saving Homes,} Buildings, and Manufacturing

- More than 6,200,000 homes have been weatherized with EERE funding provided to states or leveraged from other sources with EERE support since 1976 - creating an average energy savings of $\$ 350$ or more per year and avoiding \$1.6 billion in energy costs during winter 2005 alone for all households weatherized. ${ }^{23}$

- Due to EERE appliance standards implemented through 2012, a typical household today already saves about $\$ 180$ per year off its utility bills. Households can expect to save more than $\$ 300$ per year by 2030 , as they replace their existing appliances with newer models that use less energy - a cumulative savings to consumers of more than $\$ 900$ billion by 2020, and more than $\$ 1.6$ trillion through 2030 . The cumulative energy savings of these standards phased in through 2012 will be about 70 quadrillion British thermal units (quads) of energy through 2020, and will amount to 120 quads through 2030. (The United States consumes a total of about 100 quads of energy per year.) ${ }^{24}$

- EERE and its partners in the manufacturing sector have successfully launched 220 new, energy-efficient technologies, received 78 R\&D 100 Awards, and delivered technical assistance to more than 33,000 industrial plants. ${ }^{25}$

- Since 2005, EERE has facilitated $\$ 3.1$ billion of efficiency investments in federal government facilities from performance-based contracts, which will result in energy cost savings of approximately $\$ 8.5$ billion over the life of the energy-saving measures. The savings on utility bills and operation and maintenance created through the facility upgrades will be used to pay for the project over the term of the contract, and the agencies will continue to save money and energy after the contract term has ended. ${ }^{26}$

The Office of Energy Efficiency and Renewable Energy is at the center of creating the clean energy economy today. We lead U.S. Department of Energy efforts to develop and deliver market-driven solutions for renewable electricity generation; sustainable transportation; and energy-saving homes, buildings, and manufacturing. To learn more about the activities of the Office of Energy Efficiency and Renewable Energy, visit eere.energy.gov. If you have questions or comments about the information in this document, please contact us at EE.Communications@ee.doe.gov.

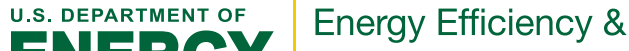 ENERGY Renewable Energy}

